\title{
A Reassessment of Tourism-Exports Led Growth Hypothesis in Africa
}

\author{
Olayinka Idowu Kareem \\ Trade and Development Policy Research Network, Ashi - Bodija, Ibadan, Nigeria
}

\begin{abstract}
In spite of Africa's potentials in tourism, its endowments have been underdeveloped and underutilized. This is not far from limited empirical studies on tourism issues. It is against this backdrop that I intend to determine the effects of tourism exports on Africa's economic growth. A panel cointegration analysis from 1990 to 2011 for thirty African countries was used to discover that tourism exports have significant positive long run effects on growth in Africa. The policy implication is that, tourism has the potentials of accelerating long run economic growth, while African growth can be use in the development of tourism exports.
\end{abstract}

Keywords: Tourism, growth, hypothesis, panel cointegration

\section{Introduction}

It has been widely acknowledged that tourism export is an important sector that if properly harnessed and promoted could serve as a form of income diversification for countries, especially developing countries that depend largely on a single source of foreign exchange earnings. This sector generates a vital amount of foreign exchange earning that also contributes to the sustainable economic growth and development of developed world. However, such component of growth has not been effectively and appropriately utilized by African countries. World Tourism Organisation (2008) report shown that in 2007, about $\$ 856$ billion was generated from 908 million of tourists (excluding transport). In the same year, the share of Africa in global tourist arrivals was about 5\% (about 45 million tourists), which is a positive figure compared to what she obtained in 2005 (which 33 million tourists or $4.3 \%$ ).

Tourism's contribution to economic growth and development could be seen from its exports, and this according to WTO (2006) represents over $40 \%$ of all services exports, which puts it as the highest category of global trade. WTO (2005) estimates put tourism to have accounted for $3 \%$ to $10 \%$ of the GDP in the developing world. Thus, we find it not surprising that tourism has become a viable export-oriented economic growth strategy for the creation of employment and the reduction of abject poverty. However, despite the popularity and increasing importance of tourism among continents of the world and particularly Africa, it has attracted relatively low attention in economic development literature. Many studies that examined crosscountry growth rates and development were often focused on the contributions of exports from either agriculture or manufacturing sectors, rather than those of the services sector of the economy. Even the little literature that focuses on service sector and more specifically on the tourism sector in developing countries are mainly concerned with the estimation and forecasting of tourism demand and income generation via the multiplier process (Naude \& Saayman, 2004; Bezmen, 2006; Odularu \& Kareem, 2007, Kareem, 2008). It is against this background that we intend to know whether tourism exports drive growth in Africa, and to ascertain if tourism exports could accelerate long run economic growth.

A review of empirical literature on tourismexport led growth (TELG) hypothesis show that most of the studies did not evaluate the long run relationship as between tourism and economic growth, but rather they show the effect of tourism exports on economic growth. Eugenio-Martin, Morales and Scarpa (2004) consider the effect of tourism on economic growth in Latin American countries from 1985 to 1998 using Arrelano-Bond dynamic panel estimation technique. Also, Sequeira and Campos (2005) examine the relationship between international tourism exports and economic growth using a panel data approach. Ledo and Iglesians (2007) evaluate the relationship between tourism activities and local development in the Spanish Urban Settlement using a time series analysis. Further, Fayissa, Nsiah and Tadasse (2007) examine the effect of tourism on economic growth in sub-Saharan African countries with the application of dynamic panel data analysis. Thus, it is as a result of this explicit gap in the literature that we intend to fill with the use of panel cointegration test in determining the long run relationship between tourism and economic growth in Africa.

Furthermore, it was discovered that there is a gap in establishing the long run relationship between tourism-exports and economic growth, 
especially at the panel data level. Balaguer and Cantavella-Jorda (2000) evaluate the role of tourism in the long run economic development of Spain using Johansen time series cointegration approach. One can understand the reason most studies have not used panel cointegration approach because it is relatively new in panel data analysis. It is as a result of this that this study tends to establish the long run relationship between tourism-exports and economic growth in Africa.

\section{Africa's Tourism Trend}

Tourism is one of the major global economic activities. Tourism is said to be an important ingredient for economic development through its impact on employment generation, enhancement of infrastructure provision, generation of income taxes, exports and by acceleration global peace (Eilat \& Einav, 2004). According to Sinclair (1999), the contribution of tourism to development is well documented and tourism is now among the fastest growing industries in the world. Competition among destinations has intensified to attract more and more tourists.

Tourism growth has been impressive in recent years and this has shown in the number of tourism arrivals in all countries that increased from 25.3 million in 1950 to 69.3 million in 1960 and later to 165.8 million in 1970. Despite the drag in the growth rate of tourist arrivals since 1970, world tourist arrival multiplied by a factor of about 27 between 1950 and 2000 (see figure 1). Thus, from
25.3 million in 1950, international tourist arrivals reached 980.0 million in 2011. In terms of global tourism receipts, the world witnessed an increase in tourism receipt from US\$2.1billion in 1950 to US\$17.9billion in 1970 and later rose to US\$106.5 billion in 1980. Due to more and more tourist arrivals in the world and with their accompany expenditure, international tourism receipts increased from US\$105 billion in 1980 to US\$479.2 billion twenty years after. This increasing trend continues till 2010, where the total global tourism receipts amounted to US\$919.0billion (see figure 2). Thus, tourism is one of the most flourishing sectors in the world given that its global receipt have grown by 12 per cent over the last ten years (Durbarry, 2001). This has led to the case where many countries are setting targets in attempts to gain the additional income, foreign currency, employment and tax revenue that the sector can provide.

It is as a result of this that many African countries have started tapping the potentialities that is embedded in tourism and hospitalities. According to Kester (2003), tourism has the potential to contribute significantly to economic growth and development in Africa. Naude and Saayman (2004) opined that Africa's cultural and natural resource endowment are such that it ought to be benefiting largely from tourism, while Christie and Crompton (2001) believe that African has "exceptional" tourism potentials and that it is increasingly contributing to the continent's gross domestic products (GDP) and exports.

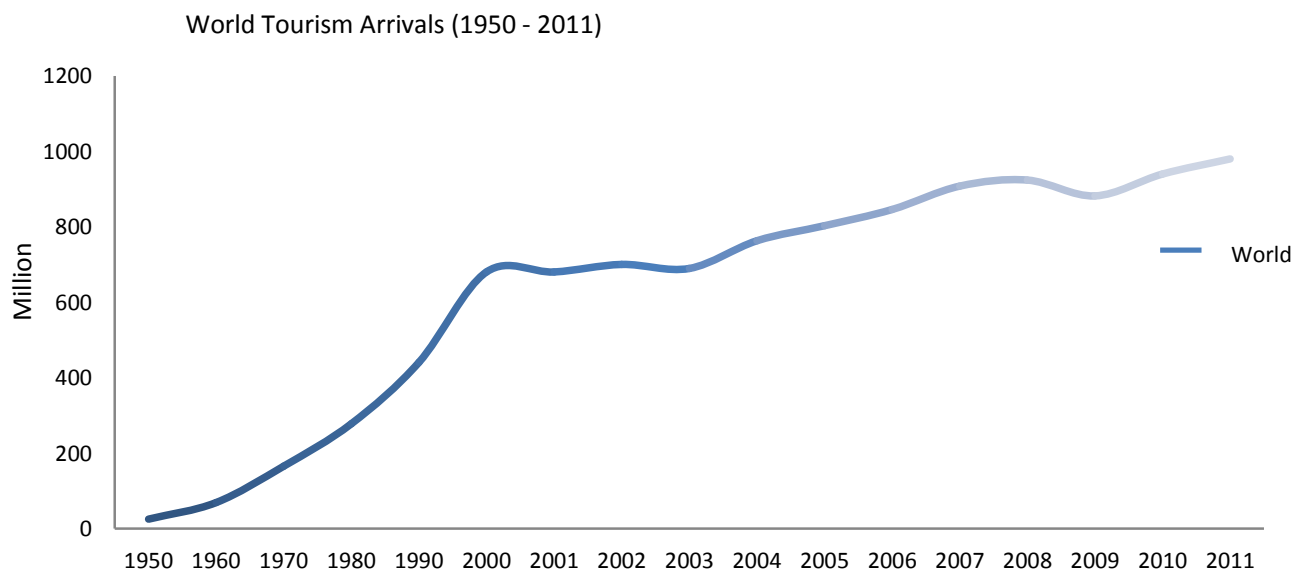

Figure 1. World tourism arrivals, 1950-2011 (Million). Source: World Tourism Organisation World Tourism Barometer (Several Issues). 


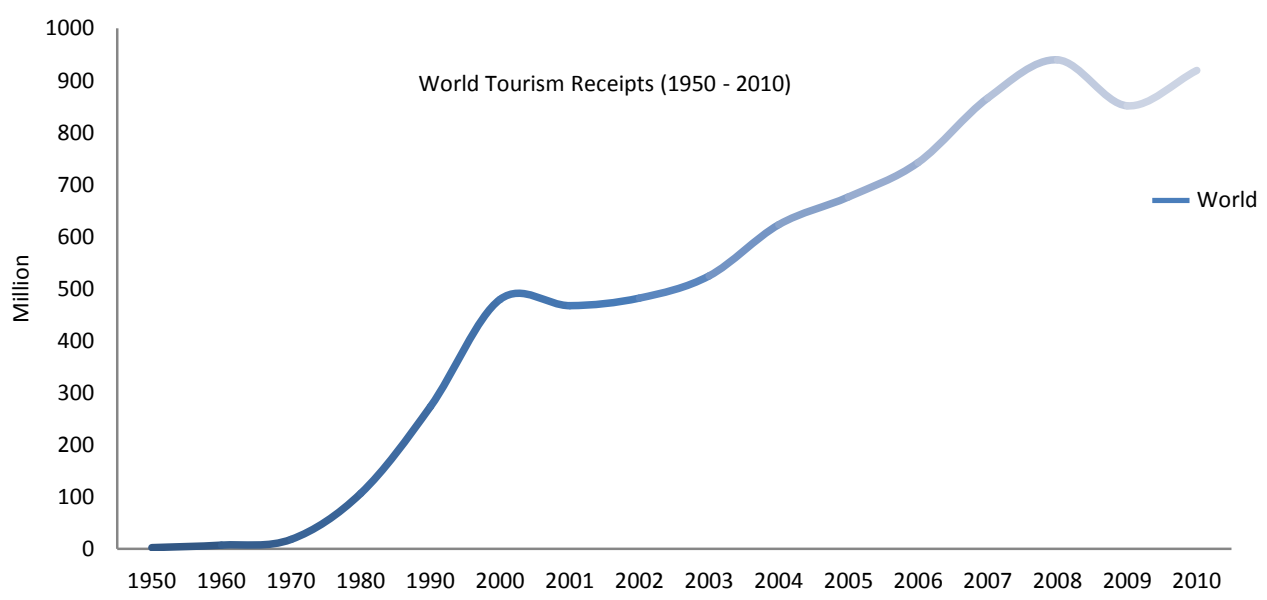

Figure 2. World tourism receipts, 1950 - 2010 (Billion). Source: World Tourism Organisation Highlights (Several Issues).

International tourist arrivals to Africa destinations increased from just 500,000 in 1950 to over 15 million in 1990 (see Figure 3). This increase in arrivals continued, reached 28.2 million in 2000 and later rose to 49.8 million in 2011. This really shows that Africa tourist arrivals have been growing overtime. According to WTO (2003) figures, Africa tourism has grown significantly since 1990. In terms of the continent's receipts on global tourism, figure 4 shows that African's receipts on international tourism rose from US $\$ 100$ million in 1950 to US\$3.4 billion in 1980, which later increased to US\$6.4 billion in 1990. By 2000, African tourism receipts have risen to US\$10.6billion and reached US\$31.6 billion in 2010.

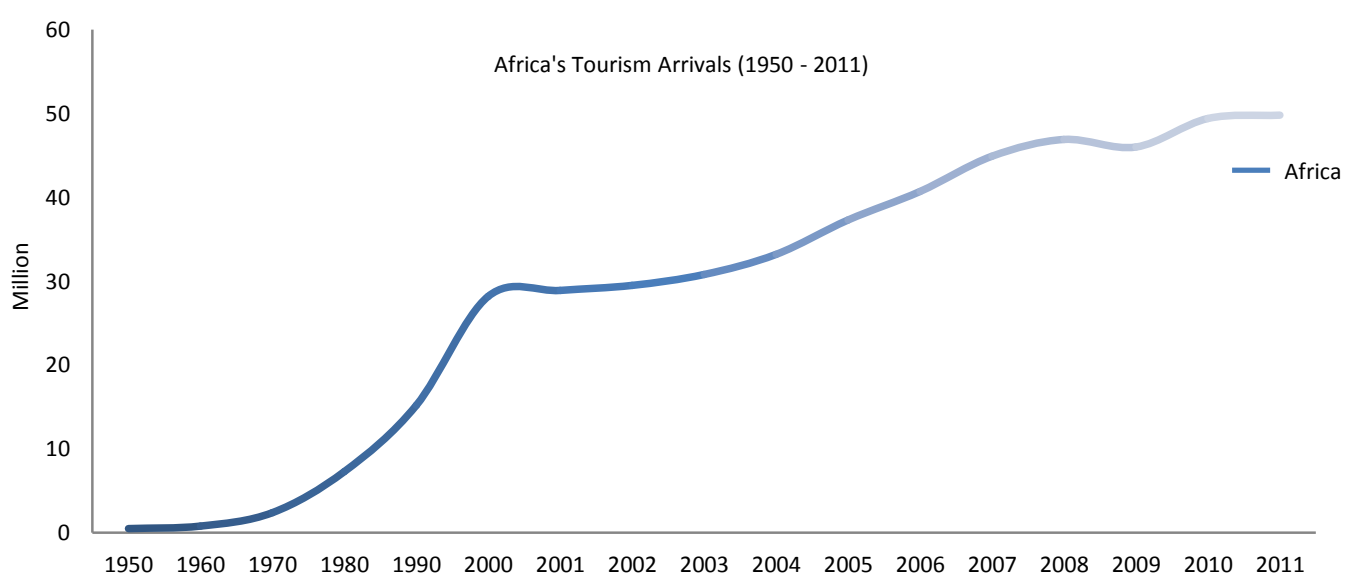

Figure 3: Africa's Tourism Arrivals, 1950 -2011 (Million).

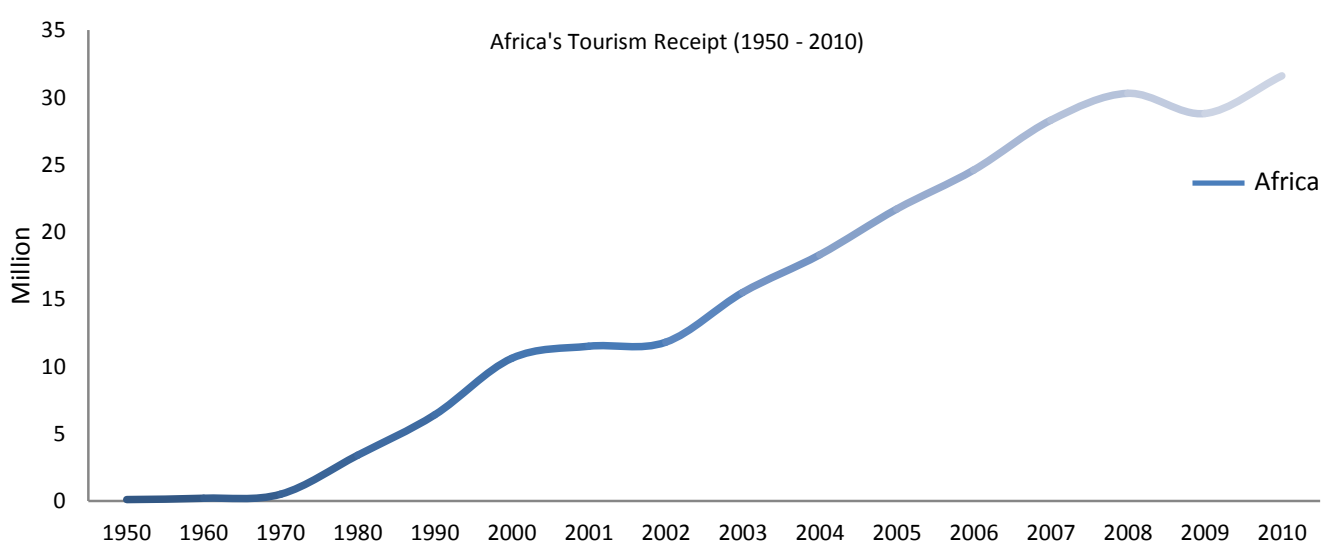

Figure 4. Africa's tourism receipt, 1950 - 2010 (Billion). Source: World Tourism Organisation Highlights (Several Issues). 


\section{Literature Review}

As it is in the export-led growth hypothesis, a tourism-led growth hypothesis postulates the presence of several arguments for which tourism export would become a main determinant of overall long run economic growth. Hitherto, it is argued that tourism brings in foreign exchange that can be used to import capital goods in order to produce goods and services in the economy, which in turn leads to economic growth. This means that it is possible for tourism to provide a remarkable part of the necessary development financing. If the earnings from tourism could be used to import capital goods or basic inputs for producing goods in any area of the economy, then, one can say that earnings from tourism are playing a fundamental role in economic development. Of course, given these potentials of tourism, it's obvious that nontourist regions will also gain from it, as a result of the distribution of the country's wealth.

However, recently, it is now acknowledged that tourism could contribute to a rise in income and economic development as it is in the export-led growth hypothesis (Adnan Hye and Ali Khan, 2013; Bouzahazah and El Menyari, 2013; Tang and Tan, 2013). First, it has the potential of enhancing efficiency through increased competition among firms and other international tourism destinations (Bhagwati and Srinivasan, 1979; Krueger, 1980; Balaguer and Cantavella-Jorda, 2000), and secondly, it facilitates the exploitation of economies of scale in local firms (Helpman and Krugman, 1985).

Further, it is seen that the bulk of the tourist's expenditure is spent on the consumption of nontraded goods and services in the host country and there exist factors that can either have a positive role or an unfavourable impact on economic growth. These non-traded goods and services are not exportable in the traditional sense due to the fact that their prices are not determined in the global market, but rather in the domestic market. The consumption of these non-tradable goods and services by tourists has effect on the relative price and availability of these non-tradable goods and services for the domestic consumers.

In the literature, a lot of articles have been written on the relationship between tourism growth and welfare where tourists consume non-tradable goods and services and these studies adopt mostly static framework. In a Komiya (1963) type firstbest model, tourism is always welfare improving. Also, Hazari and $\mathrm{Ng}$ (1993) show that in a monopoly power framework, tourism may be welfare reducing, in another article, Hazari and Sgro (1995) developed a dynamic model in which a favourable impact of a buoyant world demand for tourism would have a positive effect on the long run growth of a small economy. This favourable impact is generated by tourism behaviour as a timesaving device that allows domestic population to consume now rather than later due to the requirement of a lower saving rate. Similarly, the long run development impact of tourism in the developing countries was examined by Samimi, Sadeghi and Sadeghi (2011) using P-VAR approach during $1995-2009$. They find that there is a bilateral causality and positive long run relationship between growth and tourism development. These findings confirm the tourismled growth hypothesis.

A study on African country was conducted by Akinboade and Braimah (2010) using granger causality test to determine the impact of international tourism on economic development in South Africa from 1980 - 2005. The study demonstrates the direction of causality between international tourism earnings and long run economic growth of South Africa. They found a unidirectional causality running from tourism earnings to real GDP, both in the short run and long run. The error correction mechanism that was estimated supported this causality. Similarly, Fayissa, Nsiah and Tadesse (2007) examine the impact of tourism on economic growth and development in Africa using a panel data analysis. They discovered that tourism receipts significantly contributed to the current level of gross domestic product and the economic growth of sub-Saharan African countries as with investment in physical and human capital. Their findings indicate that African economies could enhance their short-run economic growth by strategically strengthening their tourism industry. Similar results were discovered by Bouzahazah and El Menyari (2013) when they examine the relationship between international tourism and economic growth in Morocco and Tunisia using the error correction model, cointegration and granger causality test between real tourism receipts, real effective exchange rate and economic growth from $1980-$ 2010. They concluded that the hypothesis is only valid in the short run and that the reverse of the hypothesis is the case in the long run.

A disaggregated study was conducted by Brida and Giuliani (2012) by empirically evaluating tourism-led growth hypothesis for "Tirol - Sudtirol - Trentino" Europaregion. The study looked at the sub-national transfrontier economies instead of national economies as often done in most studies. They concluded that the direct comparison amongst the results across the border regions that have a similar international tourism market provides insights in the understanding of tourism - led growth hypothesis. Further, Ledo and Iglesias (2007) study the tourist activities and local development in the Spanish urban settlement system. They intend to find out the relationship between the function of tourism, population growth and the socio-economic development, taking into 
account the type of tourist activity which is dominant. The study finds that tourism is running as an urban and territorial development factor, generating significant changes in the system of settlement.

A recent investigation of the tourism - led growth hypothesis by Adnan Hye and Ali Khan (2013) for Pakistan between 1971 - 2008 find a long term relationship between income from tourism and economic growth, but concluded that income from tourism has led to economic growth except in 2006 2008. They use autoregressive distributed lag model, while estimating with Johansen cointegration and rolling window bound testing approach to check the stability of the model. Brau, Lanza and Pigliaru (2006) analysed the empirical relationship between growth, country size and tourism specialization using a dataset covering the period 1980-2003. They discovered that tourism countries grow significantly faster than all the other sub-groups considered in the analysis. Tourism appears to be an independent determining factor for growth, the reason for that is neither because they are poorer than the average, nor because they are very open to trade. They also found that small states are fast growing only when they are highly specialized in tourism, this finding contradicting with some previous conclusions in the literature that smallness per se is not good for growth.

Katircioglu (2011) investigates the tourism led growth hypothesis in Singapore using the bound test to cointegration, error correction model and granger causality test for the period from 1960 - 2007. His results confirm the existence of long term equilibrium relationship between international tourism and economic growth using the real income growth, which converges to its log - term equilibrium level. A cross - country analysis was carried out by Cortes- Jimenez (2006), who studied the importance of the tourism sector expansion at the regional level; by focusing on two of the world wide countries with respect to tourism. The study analyzed not only the effect of international tourism but also the importance of domestic markets. Apart from analyzing the Spanish and Italian regions separately and collectively, it also took into account some criteria such as geographical location of regions. The data for the study covers the period from 1990 to 2000 using a dynamic panel-data model of the Arellano-Bond (1991) and also applied the Bruno (2005) finite sample correction. The result of the analysis shows that both domestic and international tourisms have a significant and positive role in regional economic growth, despite the fact that each of them becomes important in different scenario. Thus, domestic tourism is important for Spanish regions whilst international tourism is important in Italian regions. Furthermore, for the coaster regions and Mediterranean coast region, both domestic and international are important factors, whereas for internal regions, only domestic tourism is important.

Tang and Tan (2013) contributed to the tourism -led growth hypothesis literature by adopting the newly developed combined cointegration test and the recursive granger causality test to re-assess the stability of the tourism - led growth hypothesis in Malaysia for 12 different tourism markets. The finding suggests that growth is conintegrated with all the 1 selected tourism markets. Also, the recursive granger causality test shows that this hypothesis in Malaysia is valid and stable with respect to tourism arrivals from only 8 out of 12 tourism markets. The study concludes that not all international tourists could effectively drive the growth in Malaysia economy. Similarly, Cortes-Jimenez and Pulina (2006) assessed if exports and tourism have really promoted growth by means of the export-led growth hypothesis and the tourism-led growth hypothesis. The study used Italy and Spain as the case studies because of the fact that these countries are the main developed countries in the Mediterranean area and important countries regarding the expansion of tourism. They applied cointegration technique and multivariate granger causality test. The outcome of the analysis revealed that exports cause economic growth in the long run for both countries whilst only in Spain that tourism appears as a factor that influences economic growth in the long run.

Sequeira and Campos (2005) evaluate the effect of international tourism on economic growth using a panel data analysis. They found that on average, tourism-specialized countries grow more than others. This fact is inconsistent with economic theory as in the endogenous growth theory that suggest that economic growth is linked with sectors with high intensity in research and development (R\&D) and thus high productivity as well as large scale. This study concluded that tourism, on its own, cannot explain the higher growth rates of these countries.

Katircioglu (2008) empirically investigated the role of international tourism in the long run economic growth of Malta. The cointegration as well as granger causality techniques were applied as the main tool to identify the effect of tourism on growth on the Maltese long-run economic growth over the period 1980 to 2004 . The result of the study reveals that tourism has a positive and elastic impact on the Maltese economy. Real exchange rates depict inelastic effect on growth of Malta. The granger causality test confirms the bidirectional causality between tourism growth and economic growth in Malta. While unidirectional causation runs from external competitiveness to tourist arrivals in Malta.

Alper, Muhittin and Ferit (2008) studied the supply side to the determination of demand for tourism in Turkey by using factors such as 
infrastructure in networks and accommodation capacity in the hosting country. They used a dynamic model to estimate the demand function of tourism in Turkey with respect to its nine major clients. The conclusion of the study is that there is a minor word-of mouth effect on the consumer decision in favour of the destination. Venegas Sr. and Croes (2007) examined the causal relationship between tourism expansion and poverty for the Nicaraguan economy. Using cointegration and causality tests, the study's result lend support to the proposition that tourism has a significant positive impact on Nicaragua's economic expansion and development. The study actually used a regression analysis to carry out its analysis.

Brida and Risso (2008) investigated the relationship between tourism and economic growth for the South Tyrolean economy by using the Johansen Cointegration technique to obtain a cointegrated vector among the relevant variables. They used data from 1980 to 2006 of the GDP of South Tyrol, the number of foreign tourist in South Tyrol and the relative prices (RP) between south Tyrol and Germany. The study found that the estimated long run elasticity of the real GDG with respect to tourism demand is inelastic while the granger causality test shows that causality goes unidirectionally from tourists and RP to real GDP. They concluded that tourism -led growth hypothesis is supported empirically in the case of South Tyrol.

Kaplan and Celik (2008) investigated the impact of tourism on economic performance in Turkey over the period 1962-2006. The empirical analysis of the study was carried out with the use of VAR procedure. The result shows that there is a cointegrating vector among real output, real tourism receipts and real effective exchange rate; which simply means that tourism has a long-run effect on output. They also found that the presence of one-directional causality, indicating that tourism and exchange rates cause output.

Fayissa, Nsiah and Tadesse (2009) evaluated the effects of tourism on economic growth in Latin American countries (LAC). The study used a panel data of 17 Latin American Countries for the years that span from 1995 to 2004, which was done within the conventional neoclassical growth model framework. They discovered from empirical analysis that revenue from the tourism industry positively contributed to both the current level of gross domestic product and the economic growth of LAC as to investment in physical and human capital. The implication of their findings is that Latin American economies may enhance their economic growth by strategically strengthening the tourism industry while not neglecting the other sectors that promote growth.

Brida and Risso (2009) studied the relationship between tourism and economic growth for the South Tyrolean economy by using the Johansen cointegration analysis to obtain a cointegrated vector among the relevant variables and using the Granger causality to investigate the causality. They used annual data from 1980-2006 of the GDP of South Tyrol and the relative prices (RP) between South Tyrol and Germany. They discovered that the estimated long-run elasticity of the real GDP with respect to tourism demand is 0.29 and the Granger causality test shows that causality goes unidirectionally from tourism reinforces economic growth rate but economic growth does not reinforce tourism. The impulse response analysis shows that a shock in the number of tourists and relative prices produce a continuous and sustained positive effect.

Seetanah, Padachi and Rajid (2011) use the panel vector autoregressive framework to investigate the dynamic and endogenous contribution of tourism to growth in 40 Africa countries in the period from 1990 - 2006. The study found that African development is influenced by tourism, although private investment openness, and human capital remain the main drivers. Also, bi-directional causality exist between national income and tourism development. A country specific study was carried out by Salazar (2009) evaluates Tanzania's tourism development by looking at the troubled past, the present challenges and the prospect in the future. He opined that despite the potential of tourism in Africa, it has been operated below its potentials. Using the anthropological approach, he argued that tourism in Tanzania is firmly embedded in encompassing processes of localization, nationalization, regionalization and globalization. A good understanding of how these different scales are connected, disconnected, and reconnected and by taking into account the interest of all stakeholders involved, is the basis to integrate Africa hospitality industry that is sustainable as well as economically beneficial. The study combines archival records and recent ethnographic data to show the kinds of challenges and opportunities this poses in Tanzania.

\section{Research Methodology}

This study adapts the export-led growth hypothesis, which postulates that exports are essential ingredient for the enhancement and acceleration of long run economic growth. Theoretically, a lot of argument had been put forward to justify the export-led growth hypothesis. There are two perspectives to this hypothesis: the demand and supply side. The demand-side perspective argued that demand growth sustainability cannot be maintained in a domestic market that is small, given the fact that economic impulse based on the expansion of domestic demand is bound to be exhausted quickly. In contrast, export market cannot be exhausted and do not involve growth restriction on the demand side. Agosin (1999) 
opined that as a component of growth, exports could be a catalyst of output growth. The supplyside of export-led growth hypothesis, the expansion of exports could promote and enhance economic growth through a rise in the total factor productivity (TFP). This begins with the fact that an expansion in exports might enhance and encourage specialization in sectors that have comparative advantage in the country and it will lead to reallocation of resources from a relatively inefficient non-trade sector to the more productive export sector. Also, Helpman and Krugman (1985) opined that the growth of exports can increase productivity by offering larger economies of scale. In addition, export growth might affect total factor productivity through dynamic spillover effects on the rest of the economy (Feder, 1983).

Several studies have concentrated on the rate at which countries bridge the gap between their current positions and their destined long-run growth paths. However, to examine the responsiveness of income growth rate to revenue generated from tourism and typical sources of economic growth, we specify a neo-classical Cobb-Douglass production that was adapted from Herzer, et el. (2004) with some modifications in line with this study.

On the basis of the above theoretical background, the empirical model of the study will start with a Cobb-Douglas neo-classical production function, given the fact that Krugman and Obstfeld (2000) agreed that neoclassical model is a better model to work with than the classical and specific factor models. Since it conveys a deeper understanding of how resources may drive trade patterns. Therefore, we adopt Herzer, et al (2004) neoclassical Cobb-Douglas production function with some modifications, in terms of inclusion of some vital variables;

$$
Y_{t}=A_{t} K_{t}^{\propto} L_{t}^{\beta}
$$

Where $Y_{t}$ denotes the aggregate output of the economy at time $t,(G D P)$, and $A_{t}, K_{t}, L_{t}$ are the levels of total factor productivity, the capital stock, and the stock of labour, respectively. Given the fact that we want to know if exports affect economic growth through increasing productivity, then we assume that total factor productivity (TFP) could be expressed as a function of oil and non exports, capital goods import, investment, education and energy consumption. The rationale for inclusion of these variables is to prevent spurious conclusions regarding ELG hypothesis and to endogenize growth equation. According to Shan and Sun (1998) any study that does not consider the endogenous nature of the growth process, to a large extent, are liable to simultaneity bias and would give unreliable conclusions. Therefore, the total factor productivity is expressed as:

$$
Y_{i t}=V_{o}+\alpha K_{i t}+\beta L_{i t}+a T_{i t}+b E_{i t}+c Y_{i t-1}+d C_{i t}+\ell_{i t} \ldots \ldots \ldots(2)
$$

Where $Y_{i t}$ is the real gross domestic product of country i in time t, $K_{i t}$ is country i gross capital formation at time $\mathrm{t}, \boldsymbol{L}_{i t}$ is the labour at time $\mathrm{t}$ in country $\mathrm{i}, T_{i t}$ is the total tourist arrivals for country $\mathrm{i}, E_{i t}$ is total energy consumption, $\boldsymbol{Y}_{i t-1}$ is the past value of the real gross domestic product while $C_{i t}$ is the final consumption expenditure of tourists in destination $\mathrm{i}$ at time $\mathrm{t}$. Theoretically, in the growth equation (2), we expect each of the explanatory variables to have a direct effect on the real GDP, that is, the coefficients $\propto, \beta, a, b, c, d>0$. The dynamic panel estimation technique was adopted ${ }^{1}$, while efforts were made to test the panel properties of the panel data through panel unit test ${ }^{2}$, however, long run relationship in the model was ascertain through Pedroni panel cointegration test ${ }^{3}$.This study covers the period from $1990-2011$ for thirty African countries.

\section{The Results}

The descriptive result is shown in table 1 below. From the table, it could be seen that the average real GDP for the 35 selected African countries in this study is about $\$ 17.4$ billion during the period under review, while the corresponding tourist arrivals and total consumption expenditure for Africa are 1.02 million and $\$ 13$ billion, respectively. There is high disparity in the real GDP of the selected countries and this could be seen in the standard deviation which is high, though this is relatively low for tourist arrivals.

Table 1. Descriptive analysis.

\begin{tabular}{lcccccc}
\hline & $\boldsymbol{Y}_{i t}$ & $\boldsymbol{T}_{i t}$ & $\boldsymbol{C}_{i t}$ & $\boldsymbol{K}_{i t}$ & $\boldsymbol{L}_{i t}$ & $\boldsymbol{E}_{i t}$ \\
\hline Mean & 17385.99 & 1.019681 & 13043.42 & 3560.996 & 7308440. & 20853.83 \\
Median & 4784.875 & 0.277000 & 3318.135 & 1127.580 & 4073154. & 8530.000 \\
Std. Deviation & 33964.93 & 1.916097 & 28013.78 & 6923.191 & 9652643. & 33331.31 \\
Skewness & 3.461513 & 3.025010 & 4.623674 & 3.726204 & 2.587045 & 2.976994 \\
Kurtosis & 17.25593 & 13.04629 & 31.42325 & 20.87680 & 11.22560 & 12.87093 \\
Jacque-Bera & 4353.436 & 2309.369 & 15597.18 & 6564.570 & 1648.620 & 1528.180 \\
Observation & 416 & 403 & 419 & 420 & 419 & 276 \\
\hline
\end{tabular}




\section{The Dynamic Panel Result}

This study used two different outcomes of the dynamic generalised method of moment (GMM) analysis, vis a vis, difference and the orthogonal deviation. The dynamic analysis shows that virtually same results were obtained for both outcomes of the model ${ }^{4}$. Except for the fact that in the difference equation result, the lagged real gross domestic product is not statistically significant, while in the orthogonal deviation, all the explanatory variables are statistical significant.

Table 2. Dynamic panel result.

\begin{tabular}{lllll}
\hline Variable & Difference & & \multicolumn{2}{l}{ Orthogonal Deviation } \\
\hline & Coefficient & T-Statistic & Coefficient & T-Statistic \\
\hline$T_{i t}$ & 10.1526 & 12.1086 & 4.3259 & 12.7793 \\
$K_{i t}$ & & $(0.0000)^{* * *}$ & & $(0.0000)^{* * *}$ \\
$E_{i t}$ & 0.7358 & 3.9960 & 0.7633 & 7.1574 \\
& & $(0.0001)^{* * *}$ & & $(0.0000)^{* * *}$ \\
$Y_{i t}$ & 0.6003 & 10.8538 & 0.7487 & 18.4882 \\
$L_{i t}$ & & $(0.0000)^{* * *}$ & & $(0.0000)^{* * *}$ \\
$C_{i t}$ & 0.0585 & 0.8014 & 0.5135 & 10.0642 \\
$\mathrm{~J}-$ Statistics & -0.0006 & $(0.4238)$ & & $(0.0000)^{* * *}$ \\
\hline
\end{tabular}

Note: $* * *$ and $* * *$ denote $10 \%, 5 \%$ and $1 \%$ level of significant.

The dynamic GMM results indicate that the international tourist arrivals, a measure of tourism export has a significant direct relationship with African economic growth, such that for every tourist arrivals there will be $10 \%$ and $4 \%$ increase in the level of economic growth for the difference and orthogonal deviation, respectively. This result conform with the studies of Vanegas $\mathrm{Sr}$ and Croes (2007), Eugenio-Martin, Morales and Scarpa (2004), Fayissa, Nsiah and Tadesse (2009). Also, the gross capital formulation has a significant positive relationship with growth in African, that is, for every $100 \%$ increase in gross capital formation there will be about $74 \%$ rise for difference equation, while that of orthogonal deviation is $76 \%$ rise in African growth.

The level of energy consumption in Africa increases as economic growth rises. This shows that there has been considerable increase in the level of economic activities in the continent, though; they might be from the non-industrial activities, such as individual or domestic energy consumption. The proportion change that will occur to economic growth due to addition increase in the level of energy consumption on the average of both models is about $68 \%$. It could be seen from table 2 that economic growth in the present period responded positively to its past values. This means that, the previous values of the real GDP positively determines the present value of the real GDP. However, labour force is inversely related to African economic growth. This is due to the fact that there are pools of unemployed youths in the continent. Both models (difference and orthogonal deviation) give same results that the more the number of people in the bracket of labour force, the lower growth level experienced (see Kareem 2008). As many of the unemployed people take to antisocial vices in getting their livelihood, such as crime, fraud, rent-seeking, militancy (e.g. Niger Delta of Nigeria), etc. It is interesting to know that the level of total consumption expenditure in Africa is inversely related to economic growth. This reason that is easily available for the result is that, most of expenditures that were made in Africa were channelled to unproductive economic activities, such that it did not have any meaningful growth impact of African economies. The democratic structures of most African governments are too expensive, which give room for corruption and misappropriation of public funds that ought to have been used for the provision of infrastructures that would the growth of tourism and other sectors of their economies.

The result of the panel data properties shows that real gross domestic product $\left(Y_{i t}\right)$, tourist arrivals $\left(\boldsymbol{T}_{i t}\right)$, gross capital formulation $\left(\boldsymbol{K}_{i t}\right)$, number of labour force $\left(L_{i t}\right)$, total consumption expenditure $\left(C_{i t}\right)$ and total energy consumption ( $\left.\boldsymbol{E}_{i t}\right)$ are integrated of $\mathrm{I}(1)$ in the Levin, Lin and Chu t*, and Im, Pesaran and Shin panel unit root tests. But using the Hadri $\mathrm{Z}$ panel unit root test, they are all integrated of order zero, i.e. $\mathrm{I}(0)$ variables. This means that these variables that are integrated of order one, i.e. I(1) in the LLC and IPS unit root tests have their probability values not statistically significant at the conventional $5 \%$ significant level in the level but rather significant at their first difference (see table 3). 
Table 3. Summary of panel unit root result.

\begin{tabular}{llllllllll}
\hline Variable & \multicolumn{3}{l}{ Levin, Lin and Chu t* } & \multicolumn{3}{c}{ Im, Pesaran and Shin } & \multicolumn{3}{c}{ Hadri Z } \\
\hline \multirow{Y_{it}}{*}{} & Level & $1^{\text {st }}$ Dif. & Order & Level & $1^{\text {st }}$ Dif. & Order & Level & $1^{\text {st }}$ Dif. & Order \\
$\boldsymbol{T}_{i t}$ & 0.87 & 0.00 & $\mathrm{I}(1)$ & 1.00 & 0.02 & $\mathrm{I}(1)$ & 0.00 & - & $\mathrm{I}(0)$ \\
$\boldsymbol{E}_{i t}$ & 0.10 & 0.00 & $\mathrm{I}(1)$ & 0.99 & 0.00 & $\mathrm{I}(1)$ & 0.00 & - & $\mathrm{I}(0)$ \\
$\boldsymbol{K}_{i t}$ & 0.99 & 0.00 & $\mathrm{I}(1)$ & 1.00 & 0.03 & $\mathrm{I}(1)$ & 0.00 & - & $\mathrm{I}(0)$ \\
$\boldsymbol{L}_{i t}$ & 0.25 & 0.03 & $\mathrm{I}(1)$ & 0.50 & 0.04 & $\mathrm{I}(1)$ & 0.00 & - & $\mathrm{I}(0)$ \\
$\boldsymbol{C}_{i t}$ & 0.37 & 0.02 & $\mathrm{I}(1)$ & 0.82 & 0.01 & $\mathrm{I}(1)$ & 0.00 & - & $\mathrm{I}(0)$ \\
\hline
\end{tabular}

Note: The figures in the tables are probability values

Table 4 shows the result of the Pedroni panel cointegration test. We have used the individual intercept as the deterministic trend specification and the kernel method-Bartlett has been used for the spectral estimation, while the Newey-West automatic has been selected for the Bandwidth. The Pedroni panel cointegration test provides eleven test statistics for the panel cointegration, which evaluates the null hypothesis against both the homogenous and heterogeneous alternatives.

Table 4. Pedroni (Engle-granger based) cointegration result.

\begin{tabular}{lcrrr}
\hline \multicolumn{1}{c}{ Alternative Hypothesis: Common AR Coefs. (Within-Dimension) } & & & \\
\multicolumn{1}{c}{ Test } & Statistic & Prob. & \multicolumn{1}{l}{$\begin{array}{l}\text { Weighted } \\
\text { Statistic }\end{array}$} & Prob. \\
& & & -3.023768 & 0.0041 \\
\hline Panel V- Statistic & -3.010370 & 0.0043 & -3.387820 & 0.0000 \\
Panel rho- Statistic & 5.742668 & 0.0000 & 4.0000 \\
Panel PP- Statistic & 1.956146 & 0.0539 & -4.978444 & 0.0000 \\
Panel ADF- Statistic & 2.310925 & 0.0276 & 1.482222 & 0.1330 \\
Alternative Hypothesis: Individual AR Coefs. (Between-Dimension) & & & - \\
Group rho-Statistic & 6.506463 & 0.0000 & - & - \\
Group PP-Statistic & -7.983015 & 0.0000 & - & - \\
Group ADF-Statistic & 1.313668 & 0.1683 & - & - \\
\hline
\end{tabular}

In this study, nine of the eleven statistics in the Pedroni panel cointegration test reject the null hypothesis of no cointegration at the conventional size of 0.05 . This means that there is cointegration in the study, which establishes long run relationship between international tourism exports and economic growth in Africa. Also, the forecast ability of the tourism-export led growth hypothesis has been established in this study. That is, tourism exports could be used to forecast future economic growth in Africa and there will not be loss of information in the prediction. Thus, there is long run relationship between international tourismexports and economic growth in Africa. Kaplan and Celik (2008) and Eugenio-Martin, Morales and Scarpa (2004) got similar results.

\section{Conclusion}

In this study, we have examined the degree of association and direction of causality between international tourism exports and economic growth in Africa and at the same time show whether there is long run relationship between them. The trend of Africa's tourism-exports has been shown in comparison with other regions of the world. Further,
African sub-regional tourism exports analysis is done in order to show the sub-region that accounts for the highest tourist destinations in Africa.

The study discovered that there is a significant positive relationship between international tourism exports and economic growth in Africa. The result further shows that African growth will multiply on the average, seven times the number of tourism exports to the destinations. However, after using the panel cointegration test that is put forward by Pedroni (1999, 2004), we were able to establish that there is long run relationship between tourismexports and economic growth in Africa, which simply means that tourism could be used by African countries to drive economic growth in the continent. Also, it is discovered in this study that there is feedback causality between international tourism exports and economic growth. This is expected because most African countries still use their income to improve the level of tourism infrastructure and sites that are available in their countries in order to woo tourists to their destination so that there will be increase in the level of economic activities in the sector, which will thereby accelerate long run economic growth. The implication of this result is that tourism could be 
used to propel long run economic growth, especially with the recent drive of most African countries to diversify their economies from the natural resources dependence. Further, countries could use their growth to improve and propel tourism development.

Thus, the study concludes that African international tourism exports have the potentials of translating to long run economic growth and that the economic growth that is experienced by African countries especially the mineral exporting ones could be used to enhance tourism exports. Therefore, African countries should embark on the provision of tourism infrastructure, sites, facilities e.t.c. that can enhance tourists' choice of African destinations. Enabling tourism environment that will attract investors in the tourism industry in African destination should be put in place. While the issue of security of lives and properties of potential tourist and other factors that will enhance tourism-exports should be given utmost attention. To this end, a clear policy is necessary in order to guide the development of the sector in line with the macroeconomic aspiration of each country.

\section{Notes}

1. See Arellano and Bond (1991) for detail specification

2. For detail analyses see Maddala and Wu (1991); Hadri (1999); Choi (1999); Bharagava et al. (1982), Quah (1994), Levin \& Lin (1992), Im, Pesaran \& Shin (1997), etc.

3. Pedroni $(1999 \& 2004)$ give adequate information on panel cointegration analysis.

4. This is in terms of the signs of the degree of association and the significancy of the variables.

\section{References}

Agosin, M. (1999). Trade and growth in Chile, Cepal Review, Vol. 68, pp.79- 100 .

Akinboade, O. A. \& L., Braimoh (2010). International tourism and economic development in South Africa: A granger causality test, International Journal of Tourism Research, Vol. 12, pp.149-163.

Alper, A., Muhittin, K., Ferit (2008). International tourism demand for Turkey" A dynamic panel data approach, Munich Personal RePEc Archive Paper No. 10601, September.

Arrelano, M. \& S. Bond (1991). Some test of specification for panel data: Monte Carlo evidence and an application to employment equations, Review of Economic studies, Vol.58,pp.277-297.

Balaguer, J. \& M., Cantavella-Jorda (2000). Tourism as a longrun economic growth factor: The Spanish case, Instituto Valenciano de Investigaciones Economicas, V-2576, June.

Bezmen, T. (2006). Estimating the impact of tourism on economic development in Latin America", Paper Presented at the Academy of Economics and Finance, Houston, TX, February.

Bhagwati, J. \& T., Srinivasan (1979). Trade policy and development, in R.Dornbusch and J. Frenkel, (eds.), International economic policy: Theory and evidence, Johns Hopkins University Press, Baltimore, pp 1-35.

Bharagava, A., Franzini, L., \& W., Navendranathan (1982) Serial correlation and fixed effects model, Review of Economic Studies, Vol 49, pp.533-549.
Brau, R., Lanza, A. \& F. Pigliaru (2007). How fast are small tourist countries growing? The 1980-2003 evidence, Centro Ricerche Economiche Nord SUD Working Paper.

Breitung, J. (2000). The local power of some unit root tests for panel data, In. Baltagi (ed.), Advantages in econometrics, Vol. 15: Nonstationary Panels, Panel Cointegration, and Dynamic Panels, Amsterdam: JAI Press, pp 161-178.

Brida, J.G. \& N.A., Risso (2008). The tourism as determinant of the economic growth in South Tyrol. Retrieved form: www.ssrn.com/abstract.

Brida, J.G. \& N.A., Risso (2009). "The tourism as determinant of the economic growth in South Tyrol. Retrieved form: SSRN: www.ssrn.com/abstract.

Bruno, G.S.F. (2005). Approximating the bias of the LSDV estimator for dynamic unbalanced panel data models", Economic Letters, Vol. 87, pp361-66.

Choi, I. (1999). Unit root tests for panel data, Working Paper (Department of Economics, Kookmin University, Korea).

Christie, I.T. \& D.E., Crompton (2001). Tourism in Africa, Africa Region Working Paper, Series No.12, The World Bank Washington DC.

Chuang, Y.C. (1998). Learning by doing, the technology gap, and growth, International Economic Review, 39(3), 697 721.

Conley, T.G. (1999). GMM estimation with cross-sectional dependence, Journal of Econometrics, Vol. 92, pp 1-45.

Cortez-Jimenez and M., Pulina (2006). A further step into the ELGH and TLGH for Spain and Italy" in Fondazine Eni Enricco Mattei, Working Paper series, pp. 118-2006.

Cortes-Jimenez I. (2006). Tourism and economic growth at regional level: The case of Spain and Italy", $46^{\text {th }}$ congress of the European Regional Science Association, University of Thessaly, Volos, Greece, $30^{\text {th }}$ August- $3^{\text {rd }}$ September.

Crouch, G. (1994b). The study of international tourism demand: A review of findings, Journal of Travel Research, Vol. 33, pp. 12-23.

Dawe, D. (1996). A new look at the effects of export instability on investment and growth, World Development, 24(12), $1905-14$.

Durbarry, R. (2001). Tourism expenditure in the UK: Analysis of competitiveness using a gravity-based model, Discussion Paper Series 2001, Christie Deltaan Tourism and Travel Research Institute, University of Nothingham.

Eilat \& Einav, (2004). Determinants of international tourism: A three dimensional panel data analysis, Applied Economics 36, 1315-26.

Engle, R.F., \& C. W.J., Granger (1987). Cointegration error correction: Reprsentation, estimation and testing", Econometrica, Vol. 2, pp 251-76.

Eugenio-Martin, J., Morale, N., \& R., Scarpa (2004). Tourism and economic growth in Latin American Countries: A panel data approach, Note di Lavoro 26. 2004; Retrieved form: www.ssr.com/abstract $=504482$

Fayissa, B., Nsiah C. \& B. , Tadesse (2009). Tourism and economic growth in Latin American Countries (LAC): further empirical evidence, Department of Economics and Finance Working Paper Series, March.

Fayissa, B., Nsiah, C. \& B., Tadasse (2007). The impact of tourism on economic growth and development in Africa", Department of Economics and Finance Working Paper Series, August.

Feder, G. (1983). On exports and economic growth, Journal of Development Economics, vol. 12, 59-73

Hadri, K. (1999). Testing the Null hypothesis of stationarity against the alternative of a unit root in panel data with serially correlated errors, manuscript (Department of Economics and Accounting, University of Liverpool)

Hazari, B.R. \& A., Ng (1993). An analysis of tourists' consumption of non-traded goods and services on the welfare of the domestic consumer, International Review of Economics and Finance, Vol. 2, pp. 3-58

Hazari, B.R. and P.M., Sgro (1995). Tourism growth in a dynamic model of trade, Journal of International Trade and Economic Development, Vol. 4, pp. 253-256. 
Helpman, E. \& P., Krugman (1985). Market structure and foreign trade, MIT Press, Cambridge.

Herzer, D. Nowak-Lehmann, F. \& B. Siliverstovs (2004), Export-led growth in Chile: Assessing the role of export composition in productivity growth, Retrieved form: www.igi.wiwi.uni-goettingen.de

Im, K.S., Pesaran, M.H. \& Y., Shin (2003). Testing for unit roots in heterogeneous panels, Journal of Econometrics, Vol. 115, pp 53-74

Iyoha, M.A. (1995). Traditional and contemporary theories of external trade In: External trade and economic development in Nigeria. Selected Papers for the 1995 Nigerian Economics Society (NES) Annual Conference Proceedings, pp $1-23$.

Kao, C. (1999). Spurious Regression and Residual-Based Tests for Cointegration in Panel Data", Journal of Econometrics, Vol.90, No 1- 44 .

Kaplan, M. \& T., Celik (2008). The impact of tourism on economic performance: The case of Turkey, The International Journal of Applied Economics and Finance, 2(1): 13-18.

Kareem, O.I. (2008a). A panel data analysis of demand for tourism in Africa, Ibadan Journal of Social Sciences, Vol. 4, No.1, March

Kareem, O.I. (2008b). Determinant of tourism demand In Africa", Enzo Paci Papers Series, Volume 6, World Tourism Organisation (UNWTO) Statistics and Tourism Satellite Account, October. Retrieved form: www.unwto/statistics/malaga/malaga.htm

Katircioglu (2008). Revisiting the tourism-led-growth hypothesis for turkey using the bonds test and Johansen approach for cointegration, Tourism Management, 30(1), $17-20$.

Kester, I.G.C. (2003). International tourism in Africa, Tourism Economics, Vol. 9, pp. 203-221.

Komiya, R. (1963). Non-traded goods and the pure theory of international trade, International Economic Review, Vol. 8 pp. $132-52$

Krueger, A. (1980). Trade policy as an input to development", American Economic Review, Vol. 70, No. 188-292.

Krugman, P.R. \& M. Obsfeld (2000). International economics: theory and policy. Addison Wesley Longman, New Delhi

Ledo, P.A. \& A.M, Iglesias (2007). Tourist activities and local development in the Spanish urban settlement system, Boletin de la A.G.E., No. 45, pp. 411-13

Levin, A. \& C.F., Lin (1992). Unit root test in panel data: Asymptotic and finite sample properties, Discussion Paper, No. 92-93 (University of California at San Drego).

Maddala, G.S. (1999). On the use of panel data methods with cross country data, Amales DÉconomie et de Statistique, Vol. 55-56, pp 429-448.

Maddala, G.S. \& S. Wu (1999). A comparative study of unit root tests with panel data and a new simple test, Oxford Bulletin of Economics and Statistics, Vol. 61, 631-52.

Naude, W.A. \& A. Saayman (2004). The determinants of tourism arrivals in Africa: A panel data regression analysis, A paper Prepared for the International Conference, Centre for the Study of African Economics, St. Catherine's College, University of Oxford, 21-22 March.

Odularu, G. O. \& O.I., Kareem (2007). Tourism and reputation in Africa: A panel data analysis, African Journal of Economic Policy, 14(2), December.

Okoh, R.N., (2004). Global integration and the growth of Nigeria's non-oil exports, A Paper Presented at the African Conference, 21-22 March, Oxford, U.K
Overseas Development Institute (2007). Can tourism offer propoor pathways to prosperity?: Examining evidence on the impact of tourism on poverty, ODI Briefing Paper, June.

Pedroni, P. (1999). Critical values for cointegration tests in heterogeneous panels with multiple regressors", Oxford Bulletin of Economics and Statistics, Vol. 61, pp. 653-70

Pedroni, P. (2004). Panel cointegration; Asymptotic and finite sample properties of pooled time series tests with an application of the PPP hypothesis, Econometric Theory, Vol.20, pp. 597-625.

Phillips, P.C.B \& H.R., Moon (1999). Linear regression limit theory for nonstationary panel data, Econometrics, Vol. 67, pp 1057-1111

Quah, D. (1994). Exploiting cross-section variation for unit root inference in dynamic data, Economics Letters, Vol. 44, pp 9-19

Riezman, R.G. Summers, P.M \& C.H. Whiteman (1996). The engine of growth or its Handmaiden? A time series assessment of export-led growth, Empirical Economics, vol. 21, pp $77-113$.

Sachs, J. \& A. Warner (1995). Economic reform and the process of global integration, Brookings, papers on Economic Activity, Vol. 1, pp $1-118$

Salazar, N. B. (2009). A troubled past, challenges present, and a promising future: Tanzania's tourism development in perspective, Tourism Review International, vol. 12.

Samimi, A. J., Sadeghi, S. \& S., Sadeghi (2011). Tourism and economic growth in developing countries: P-VAR Approach, Middle-East Journal of Scientific Research, 10 (1), pp $28-32$.

Sequeira, T.N. \& C., Campos (2005). International tourism and economic growth: A panel data approach, The Fondazione Eni Enrico Matteir Note di Lavoro Series Index: Retrieved form: www.feem.it/feem/pub/publication/Wpapers.

Seetanah, B., Padachi, K. and S., Rojid (2011). Tourism and economic growth", African evidence from panel vector autoregressive framework, UNU-WIDER Working Paper No.2011/33.

Shan, J. \& F. Sun (1998). On the export - led growth hypothesis: the econometric evidence from China, Applied Economics, 30, 1055-65.

Sinclair, M.T. (1999). Tourism and economic development: A survey, Journal of Development Studies, 34(5), No. 1-51.

Todaro, M.P (1997). Economics for developing world: An introduction to principles, problems and policies for development, Longman, London, pp $306-310$

Vanegas Sr., M. \& R., Croes (2007). Tourism, economic expansion and poverty in Nicaragua: Investigating cointegration and causal relations, Staff Paper Series P0710 , June.

World Bank (2007), World development indicators, CD Database, Washington D.C.

World Tourism Organisation (2003). Tourism highlights, Edition (2003), WTO: Madrid.

World Tourism Organisation (2005). Tourism market trends, November.

World Tourism, Organisation (2003c). WTO World Tourism Barometer, Vol. 1, No.1.

World Tourism Organisation (2006). Africa: A key resource for economic and social development, Global envision, October 16.

World Tourism Organisation (2008). Tourism highlights. Edition 2008, Retrieved form: www.unwto.org.

World Tourism Organisation (2009). Tourism highlights. January Edition 2009, Retrieved form: www.unwto.org. 